Document downloaded from:

http://hdl.handle.net/10251/83619

This paper must be cited as:

Miró Richart, P.; Marín García, ML.; Miranda Alonso, MÁ. (2016). Radical-mediated dehydrogenation of bile acids by means of hydrogen atom transfer to triplet carbonyls. Organic and Biomolecular Chemistry. 14(9):2679-2683. doi:0.1039/c5ob02561c.

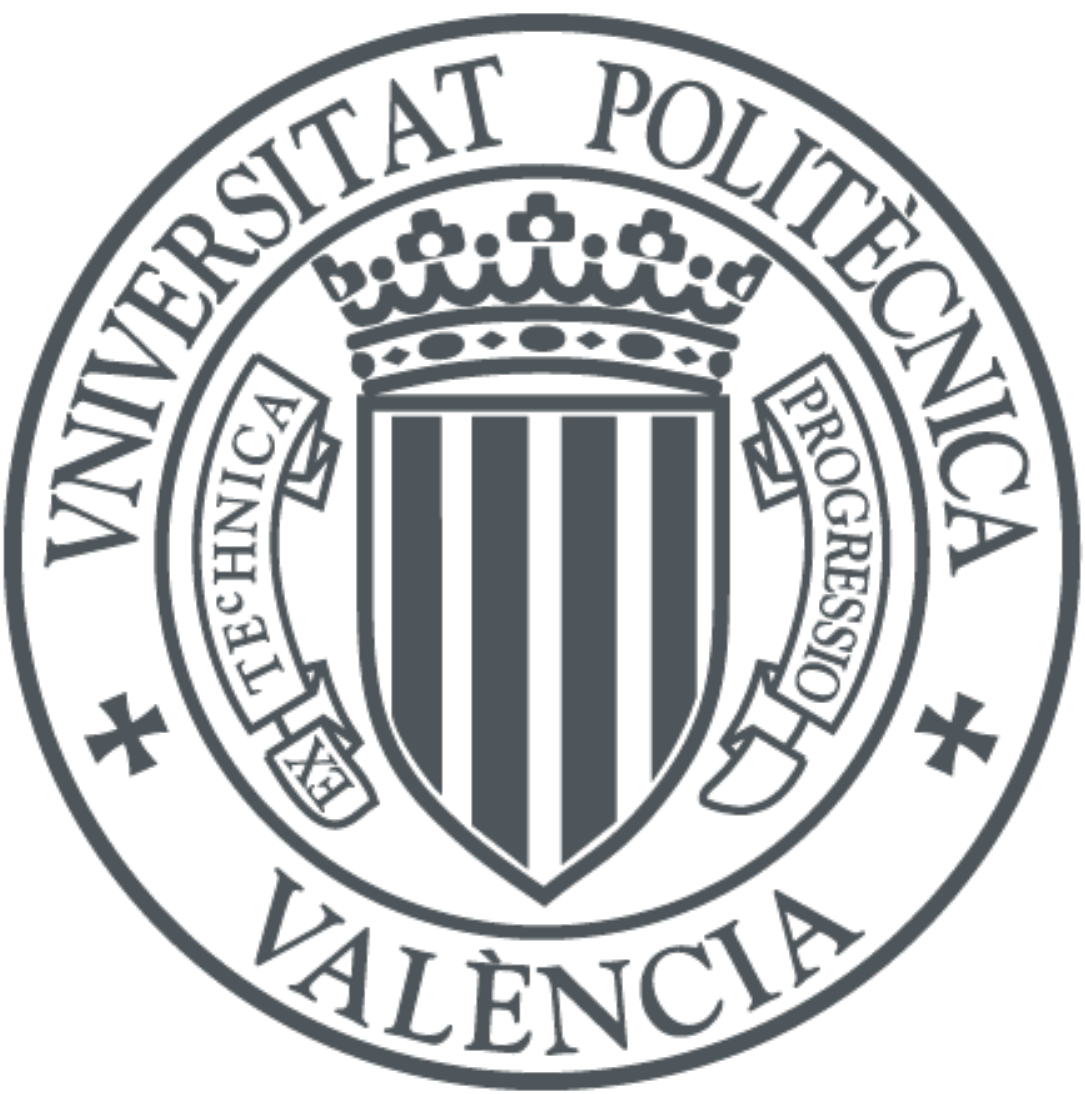

The final publication is available at

http://doi.org/10.1039/c5ob02561c

Copyright Royal Society of Chemistry

Additional Information 


\title{
Radical-mediated dehydrogenation of bile acids by means of hydrogen atom transfer to triplet carbonyls 1
}

\author{
P. Miro , M. L. Marin * and M. A. Miranda * \\ Instituto Universitario Mixto de Tecnología Química (UPV-CSIC), Departamento de \\ Química. Universitat Politècnica de València, Avda. los Naranjos s/n 46022, Valencia, \\ Spain.E-mail:mmiranda@qim.upv.es; marmarin@qim.upv.es
}

Received 14th December 2015 , Accepted 21st January 2016

First published on the web 22nd January 2016

The aim of the present paper is to explore the potential of radical-mediated dehydrogenation of bile salts (BSs), which is reminiscent of the enzymatic action of hydroxysteroid dehydrogenase enzymes (HSDH). The concept has been demonstrated using triplet carbonyls that can be efficiently generated upon selective UVA-excitation. Hydrogen atom transfer (HAT) from BSs to triplet benzophenone (BP) derivatives gave rise to radicals, ultimately leading to reduction of the BP chromophore with concomitant formation of the oxo-analogs of the corresponding BSs. The direct reactivity of triplet $\mathrm{BP}$ with $\mathrm{BSs}$ in the initial step was evaluated by determining the kinetic rate constants using laser flash photolysis (LFP). The BP triplet decay was monitored $\left(\lambda_{\max }=520 \mathrm{~nm}\right)$ upon addition of increasing BS concentrations, and the obtained rate constant values indicated a reactivity of the methine hydrogen atoms in the order of C-3 < C-12<C-7. The steady-state kinetics of the overall process, monitored through the disappearance of the typical BP absorption band at $260 \mathrm{~nm}$, was much faster under $\mathrm{N}_{2}$ than under $\mathrm{O}_{2}$, also supporting the role of the oxygen-quenchable triplet in the dehydrogenation process. Furthermore, irradiation of deaerated aqueous solutions of sodium cholate in the presence of KPMe provided the oxo-analogs, 3[O],7[O]-CA, $3[\mathrm{O}]-\mathrm{CA}$ and $7[\mathrm{O}]-\mathrm{CA}$, arising from the HAT process.

\section{Introduction}

Bile acids (BAs) are a family of amphiphilic steroids that play a pivotal role in a wide variety of physiological functions, such as elimination of cholesterol or solubilization of 
lipids. $\stackrel{-1-3}{ }$ Chemically they share a steroidal skeleton with an unusual $\mathrm{cis}$ fusion between rings $\mathrm{A}$ and $\mathrm{B}$, a short lateral chain ending in a carboxylic moiety and different numbers of hydroxyl groups on the $\alpha$-face. These structural characteristics contribute to their facial amphiphilia, associated with a convex hydrophobic $\alpha$-face and a concave and hydrophilic $\beta$-face (Fig. 1). ${ }^{ \pm}$Primary BAs, cholic acid (CA) and chenodeoxycholic acid (CDCA), are biosynthesized directly from cholesterol in the hepatocytes of the liver; secondary BAs, deoxycholic acid (DCA) and lithocholic acid (LA), are produced in the colon by enzymatic deoxygenation of the hydroxyl group at the $\mathrm{C}-7$ position of $\mathrm{CA}$ and CDCA respectively. Ursodeoxycholic acid (UDCA) is the epimer of CDCA at C-7 and is also found at low concentrations in humans. $\frac{5.6}{6}$ The amphiphilic properties of BAs allow aggregation in aqueous solution by the interaction of the $\beta$-faces of the monomers, giving rise to the primary aggregates, that agglomerate as the concentration increases. $\stackrel{-\underline{-9}}{ }$

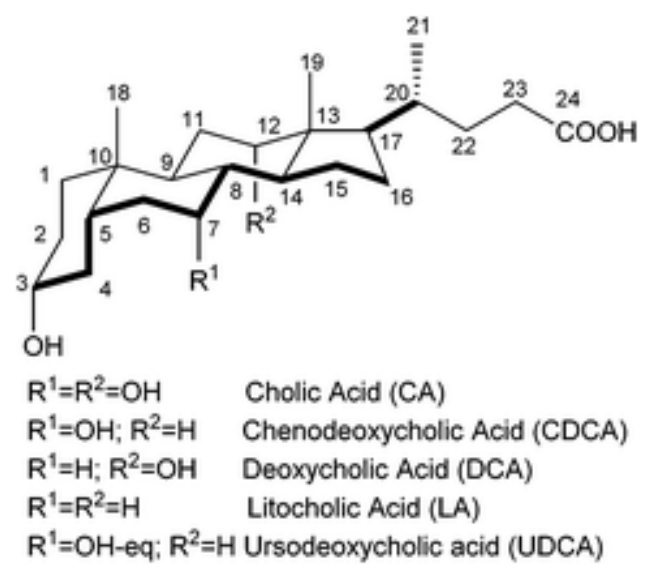

Fig. 1 Chemical structure of bile acids.

Bacterial transformations of BAs have recently attracted considerable interest in connection with diseases of the human gastrointestinal tract and, more specifically, colon cancer..$^{10}$ In addition, products obtained in the biotransformation of BAs by bacteria have been exploited in the commercial production of biologically active compounds. 11

The microbial transformations of BAs include dehydrogenation of the $\alpha-\mathrm{OH}$ groups at positions $\mathrm{C}-3, \mathrm{C}-7$ and/or $\mathrm{C}-12$, which results in the oxidation to the corresponding oxo-derivatives in a reversible, regio and stereoselective manner. ${ }^{12}$ In general, these processes are driven by hydroxysteroid dehydrogenases (HSDHs) that belong to the family of oxidoreductase type enzymes and use the nicotinamide adenine cofactors $\mathrm{NADPH} / \mathrm{NADP}^{+}$or $\mathrm{NADH} / \mathrm{NAD}^{+}$with an efficient recycling system, ${ }^{13}$ such as the pyruvate/lactate pair (i․ 2).

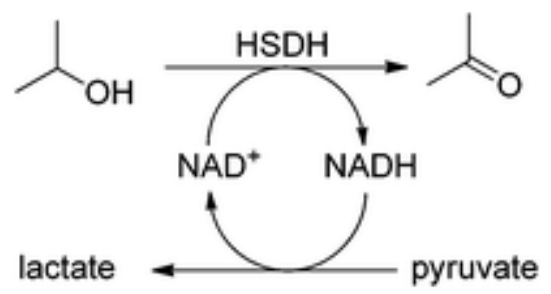

Fig. 2 An example of hydroxysteroid dehydrogenase (HSDH) performance. 
The potential of HSDHs as a tool to discover new lead compounds for the pharmaceutical industry has been explored by means of combinatorial biocatalyzed approaches. This strategy has been effectively used to generate libraries of BA derivatives suitable for high-throughput biological screening." 1 An interesting application is the chemoenzymatic/multienzymatic synthesis of UDCA,, 14.15 a drug used to dissolve cholesterol gallstones. 16

With this background, the aim of the work described in the present paper is to explore the potential of radical-mediated dehydrogenation of bile salts (BSs), which would be reminiscent of the enzymatic action of HSDH. As this new approach is based on a different reaction mechanism, it could allow, after optimization, the achievement of complementary regio and stereoselectivities that could expand the available synthetic toolbox. To prove the concept, carbonyl triplets, such as those of benzophenone (BP) derivatives (Fig. 3), have been chosen because they can be efficiently generated upon selective UVA-excitation and have reactive $n \pi *$ electronic configuration. In fact, they are known to act as formal biradicals, mediating $\mathrm{H}$-abstraction from allylic positions in

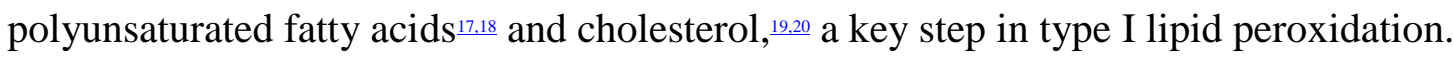

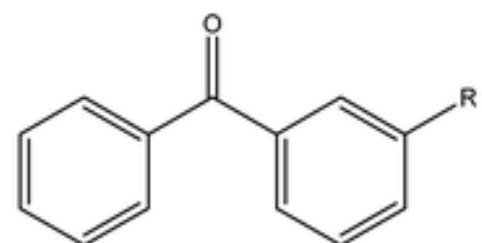

$\mathrm{R}=\mathrm{H} \quad$ Benzophenone $(\mathrm{BP})$

$\mathrm{R}=\mathrm{CH}\left(\mathrm{CH}_{3}\right) \mathrm{COOH}$ Ketoprofen $(\mathrm{KP})$

$\mathrm{R}=\mathrm{CH}\left(\mathrm{CH}_{3}\right) \mathrm{COOCH}_{3}$ Ketoprofen methyl ester (KPMe)

Fig. 3 Chemical structures of BP and BP-derivatives.

In spite of the intensive efforts devoted to developing alcohol oxidation methodologies, the photochemical dehydrogenation for synthetic purposes remains almost unexplored, and the reported examples are essentially restricted to benzyl alcohols.21

\section{Results and discussion}

A simplified picture of the radical-mediated approach to achieve dehydrogenation of BSs is shown in Fig. 4. It involves generation of free radicals through hydrogen atom transfer (HAT) from BSs to triplet BP derivatives, ultimately leading to reduction of the BP chromophore concomitantly with formation of the oxo-analogs of the corresponding BSs. Accordingly, the direct reactivity of triplet BP with BSs in the initial step was evaluated by determining the kinetic rate constants using laser flash photolysis (LFP), and the overall reaction was monitored through the disappearance of the typical BP absorption band at $260 \mathrm{~nm}$. The outcome of the reaction was assessed by isolation and full spectroscopic characterization of the dehydrogenated BS products. 


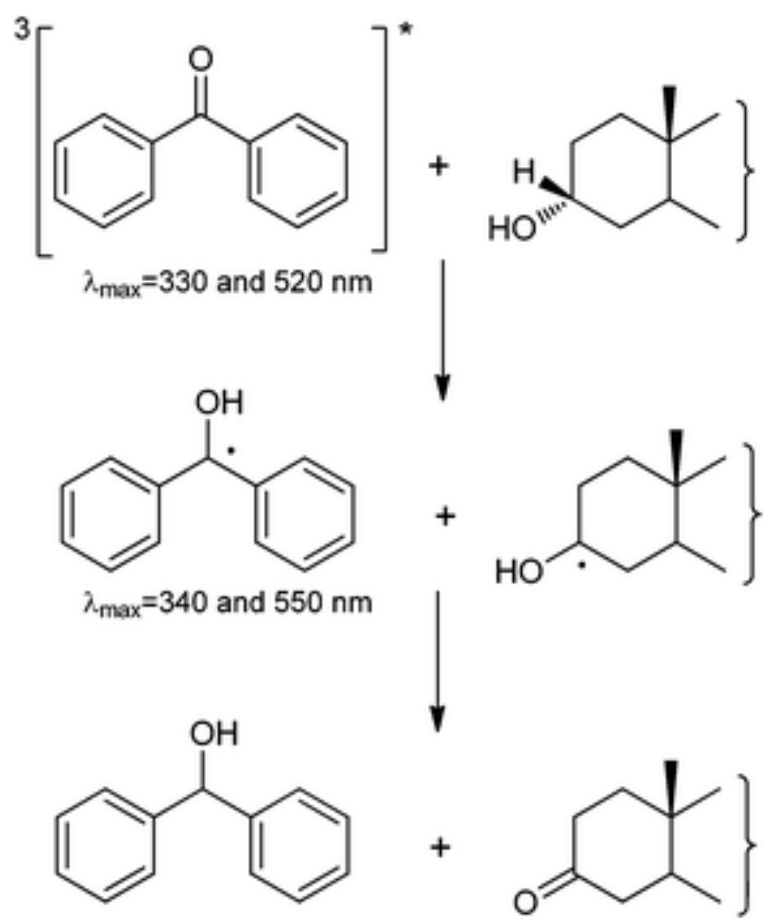

Fig. 4 Simplified mechanistic scheme of the radical-mediated dehydrogenation of the $3 \alpha$-position of a BS, triggered by a triplet carbonyl.

\section{Generation and detection of free radicals}

The generation and behavior of the triplet excited state of the BP chromophore in the presence of BSs was investigated by LFP. Thus, upon laser excitation $(\lambda=266 \mathrm{~nm})$ of ketoprofen methyl ester $(\mathrm{KPMe})$ in a deaerated saline aqueous solution $([\mathrm{NaCl}]=0.2$ $\mathrm{M})$, a transient absorption spectrum with two bands peaking at 330 and $520 \mathrm{~nm}$, characteristic of the triplet excited state $\left({ }^{3} \mathrm{KPMe}^{*}\right)$, was observed (Fig. 5 top). However, when the spectrum was taken in the presence of BSs (NaCA, NaCDCA, NaDCA, NaLA or NaUDCA) a new transient signal with two maxima at 340 and $550 \mathrm{~nm}$, characteristic of the benzhydryl radical (KPMe-H') was observed in all cases as a proof of the HAT process (see Fig. 5 bottom). The time-evolution of the two species was markedly different, with $\mathrm{KPMe}-\mathrm{H}^{*}$ decaying much slower than ${ }^{3} \mathrm{KPMe}$. 

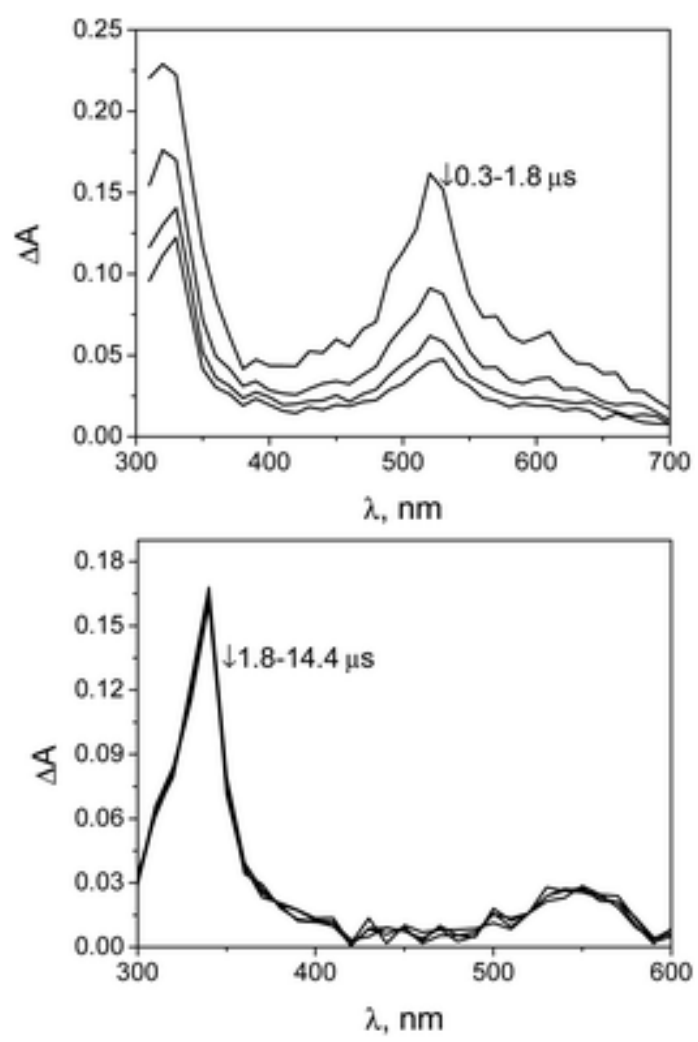

Fig. 5 Transient absorption spectra $\left(\lambda_{\text {exc }}=266 \mathrm{~nm}\right)$ obtained for deaerated aqueous solutions $([\mathrm{NaCl}]=0.2 \mathrm{M})$ of KPMe $\left(1 \times 10^{-5} \mathrm{M}\right)$ in the absence (top) or in the presence of NaCA (15 mM, bottom), at different times after the laser pulse.

\section{Radical-mediated reactivity}

To quantify the reactivity of ${ }^{3} \mathrm{KPMe} *$ with $\mathrm{BSs}$, the quenching rate constants were determined. Hence, the triplet decay was monitored $\left(\lambda_{\max }=520 \mathrm{~nm}\right)$ upon increasing BSs concentrations and, in fact, a progressive shortening was observed in all cases (see Fig. 6 top for NaCA as a representative example). The reverse of the triplet lifetime was plotted versus BS concentrations, and the corresponding rate constant values were obtained from the slopes of the linear fittings (Fig. 6 bottom and Table 1). In general, the observed reactivity for the initial HAT step followed the same trend as the number of $\mathrm{CHOH}$ moieties in the $\mathrm{BS}$, thus indicating that the isopropanol-like methine hydrogens are indeed the most reactive sites. 

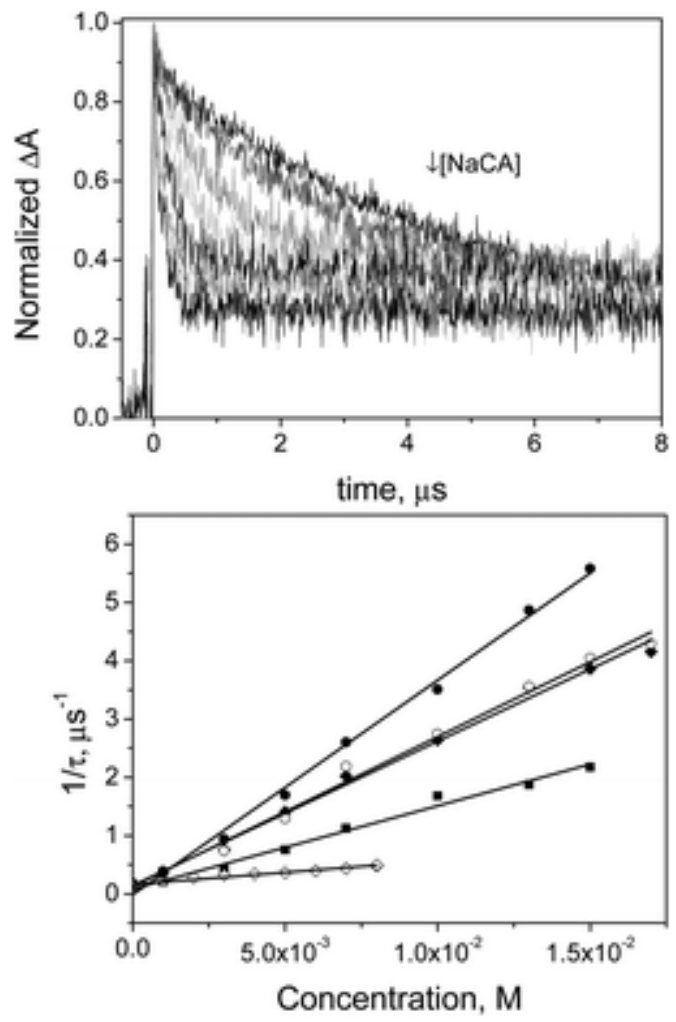

Fig. 6 Top: kinetic traces recorded at $520 \mathrm{~nm}$ after laser flash irradiation $\left(\lambda_{\mathrm{exc}}=266 \mathrm{~nm}\right)$ of deaerated aqueous solution $([\mathrm{NaCl}]=0.2 \mathrm{M})$ of KPMe $\left(1 \times 10^{-5} \mathrm{M}\right)$ in the presence of increasing concentrations of NaCA $(0-17 \mathrm{mM})$ as an example. Bottom: Stern-Volmer plots of the reciprocal KPMe triplet lifetime versus $[\mathrm{NaCA}](\bullet),[\mathrm{NaCDCA}](\diamond)[\mathrm{NaDCA}](\boldsymbol{\bullet}),[\mathrm{NaLA}](\diamond)$ and [NaUDCA] (०).

Table 1 Determined quenching rate constants for the reaction of ${ }^{3} \mathrm{KPMe}^{*}$ with BSs

BS

$\mathrm{NaCA}$

$\mathrm{NaCDCA}$

$\mathrm{NaDCA}$

NaLA

NaUDCA
$k_{\mathrm{q}}\left(\mathbf{M}^{-1} \mathbf{s}^{-1}\right)$

\section{$3.7 \times 10^{8}$}

$2.5 \times 10^{8}$

$1.4 \times 10^{8}$

$4.1 \times 10^{7}$

$2.6 \times 10^{8}$

The regioselectivity of HAT was evaluated by comparing the quenching rate constants obtained for NaCDCA, NaDCA and NaUDA, having the same number of $\mathrm{CHOH}$ moieties. The values found for NaCDCA and NaUDCA having the two hydroxyl groups at C-3 and C-7 (either on the $\alpha$ - or $\beta$-face) were similar; by contrast, a remarkably lower value was found for NaDCA whose hydroxyl groups were at C-3 and C-12. Assuming an additive effect and comparing these values to the one obtained for NaLA, in which only one hydroxyl group (at C-3) is present, the contribution of each 
position could be inferred. Therefore, the order of reactivity of the hydrogen atom in the HAT step was C-3 < C-12<C-7. Nonetheless, it has to be considered that the processes occurring to the long-lived radical species KPMe- ${ }^{*}$ are much slower than the initial HAT; hence, the rate determining step for the overall reaction is not triplet quenching by the BSs.

The steady-state photolysis of KPMe with NaCA in solution was monitored by UVspectrophotometry, following the characteristic KPMe band at $260 \mathrm{~nm}$ (Fig. 7). As expected for a triplet reaction, the kinetics was much faster under $\mathrm{N}_{2}$ than under $\mathrm{O}_{2}$, supporting the role of the oxygen-quenchable ${ }^{3} \mathrm{KPMe} *$ in the dehydrogenation process.

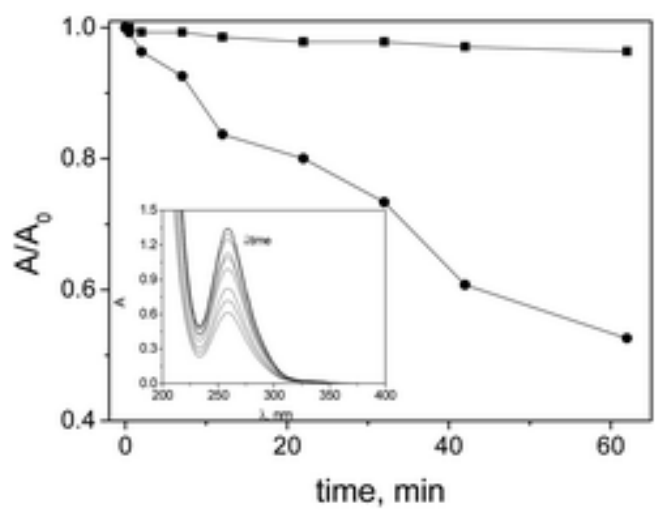

Fig. 7 Relative absorbance of KPMe measured at $260 \mathrm{~nm}$ versus irradiation time $\left(\lambda_{\text {irr }}\right.$ centered at 350 $\mathrm{nm})$ in aqueous solutions $([\mathrm{NaCl}]=0.2 \mathrm{M})$ containing KPMe $\left(8 \times 10^{-5} \mathrm{M}\right)$ and $\mathrm{NaCA}\left(1 \times 10^{-2} \mathrm{M}\right)$ under a $\mathrm{N}_{2}(\bullet)$ or an $\mathrm{O}_{2}(\boldsymbol{\bullet})$ atmosphere. Inset: UV-Vis spectra of KPMe $\left(8 \times 10^{-5} \mathrm{M}\right)$ and $\mathrm{NaCA}$ $\left(1 \times 10^{-2} \mathrm{M}\right)$ under $\mathrm{N}_{2}$ at different irradiation times.

\section{Isolation and characterization of dehydrogenated BA derivatives}

Initially, for analytical purposes, an acetonitrile solution of the methyl ester of CA $(\mathrm{CAMe})$ and BP was irradiated $\left(\lambda_{\text {irr }}\right.$ centered at $\left.350 \mathrm{~nm}\right)$ under a $\mathrm{N}_{2}$ atmosphere. The resulting crude photomixture was concentrated and purified by column chromatography yielding three products (Fig. 8). Their structural characterization was based on ${ }^{1} \mathrm{H}$ and ${ }^{13} \mathrm{C}$ NMR spectroscopy, including NOEDIFF experiments, combined with exact mass determination. The first eluted product (A) showed a loss of four amu in the MS, together with the appearance of two new ${ }^{13} \mathrm{C}$ signals at $>210 \mathrm{ppm}$ and the disappearance of two of the signals in the $65-75 \mathrm{ppm}$ region, thus pointing to the oxidation of two out of the three hydroxyl groups. Moreover, the second (B) and third (C) eluted products showed a loss of two amu in the MS and the displacement of one ${ }^{13} \mathrm{C}$ signal from $65-75$ ppm to $>210$ ppm; thus, the oxidation of one of the hydroxyl groups at C-3, C-7 or C-12 was inferred in both cases. To unequivocally characterize the three photoproducts, NOEDIFF experiments were performed, and the resulting spectra were thoroughly analyzed. Compound $\mathbf{A}$ was unambiguously assigned as the compound resulting from the oxidation at C-3 and C-7 positions, 3[O],7[O]-CAMe. In fact, irradiation of proton at $4.06 \mathrm{ppm}$ produced a NOE effect on methyl groups at 0.98 (d) and 0.72 (s) ppm. This indicates that the proton at $4.06 \mathrm{ppm}$ corresponds to $12 \beta-\mathrm{H}$, and the methyl groups to $21-\mathrm{CH}_{3}$ and 19- $\mathrm{CH}_{3}$. Furthermore, irradiation of the methyl group at $1.28 \mathrm{ppm}$ resulted in a NOE effect only on the signal at $0.72 \mathrm{ppm}$, indicating that the former corresponds 
to $18-\mathrm{CH}_{3}$. Compound $\mathbf{B}$ was identified as arising from the oxidation at $\mathrm{C}-3$, namely $3[\mathrm{O}]-\mathrm{CAMe}$, based on the NOE enhancement on methyl groups at 0.97 (s and d) and on the proton at $4.03 \mathrm{ppm}$ upon irradiation of the methyl group at $0.72 \mathrm{ppm}$. From this result, the methyl group at $0.72 \mathrm{ppm}$ can be assigned to $19-\mathrm{CH}_{3}$ and the singlet at 4.03 $\mathrm{ppm}$ to $12 \beta-\mathrm{H}$. In fact, when the latter was irradiated, a NOE effect was found on 19$\mathrm{CH}_{3}(0.72 \mathrm{ppm})$ and $21-\mathrm{CH}_{3}(0.97 \mathrm{ppm}, \mathrm{d})$, while irradiation of a proton at $3.92 \mathrm{ppm}$ did not result in any NOE effect on the methyl groups indicating that this signal corresponds to $7 \beta-\mathrm{H}$. Finally, compound $\mathbf{C}$ was identified as the one resulting from oxidation at the $\mathrm{C}-7$ position, namely 7[O]-CAMe, based on the NOE effect observed on the methyl groups $21-\mathrm{CH}_{3}(\mathrm{~d})$ and $19-\mathrm{CH}_{3}$ (s) upon irradiation on $12 \beta-\mathrm{H}(4.02 \mathrm{ppm})$.

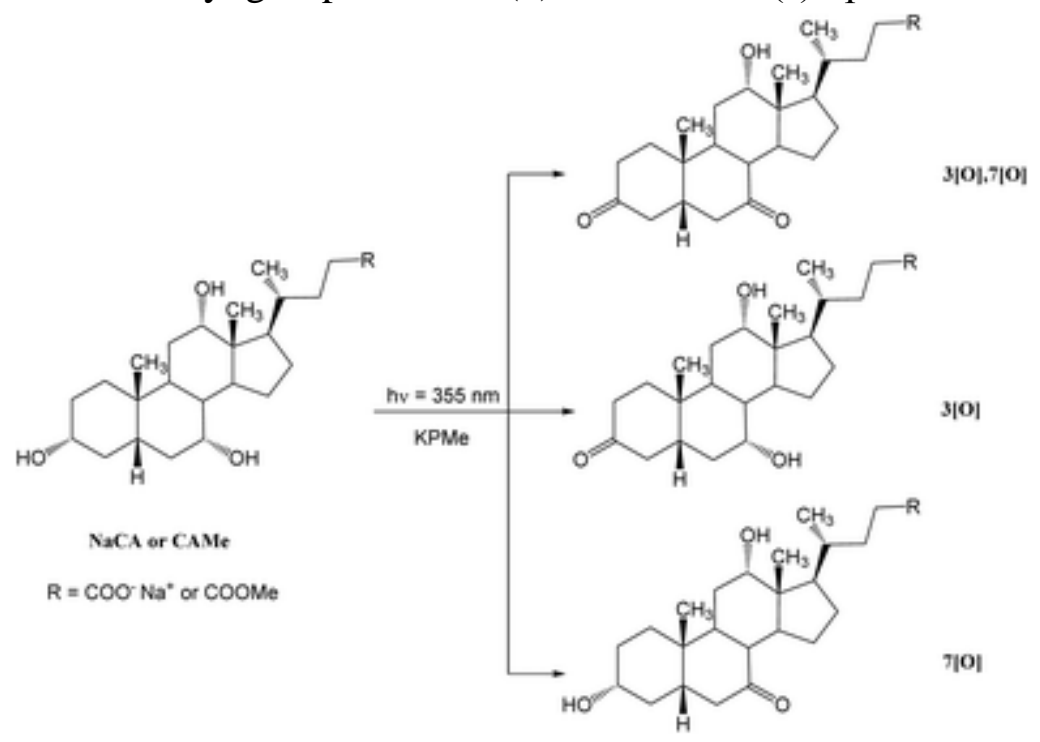

Fig. 8 Irradiation $\left(\lambda_{\text {irr }}\right.$ centered at $\left.350 \mathrm{~nm}\right)$ of CAMe or NaCA in the presence of KPMe in deaerated $\mathrm{MeCN}$ or $\mathrm{H}_{2} \mathrm{O}$ solution, respectively.

After isolation and unequivocal characterization of the methyl esters, the three oxoanalogs were subjected to saponification and used to monitor the kinetics of the photooxidation of $\mathrm{NaCA}$ in deaerated aqueous solution $([\mathrm{NaCl}]=0.2 \mathrm{M})$, in the presence of KPMe, to mimic the conditions used in the LFP experiments. The kinetics of the photooxidation was monitored by UPLC-MS operating in negative ionization mode. The obtained results (see Fig. 8 as well as Fig. S1 and Tables S1-S4 in ESI $\dot{\perp}$ ) indicate that again the main photoproducts arise from the oxidation at C-3 and/or C-7.

Although the rate constants determined by LFP could, in principle, appear inconsistent with the product distributions obtained in steady-state photolysis, the observed differences can be explained taking into account the fact that the rate constants are associated with the initial step while the product distributions are the result of the global process that includes disproportionation or reversible HAT in the primary radical pair. Indeed, the long lifetime of $\mathrm{KPMe}-\mathrm{H}^{*}$ supports that the subsequent processes occurring from this species are in the origin of the observed regioselectivity.

\section{Conclusions}


Dehydrogenation of bile acids at positions C-3 and/or C-7 has been achieved by a radical-mediated mechanism, which is reminiscent of the enzymatic action of hydroxysteroid dehydrogenases. The triplet excited states of benzophenone derivatives, generated upon selective UVA-excitation, have proven to be appropriate radical precursors, which operate through hydrogen atom transfer from the methine $\mathrm{CHOH}$ groups. As this new approach is based on a different reaction mechanism, it could allow, after optimization, achievement of complementary regio and stereoselectivities that could expand the available synthetic toolbox.

\section{Experimental}

\section{Irradiation of CAMe with BP}

A solution of CAMe $(0.557 \mathrm{~g}, 1.37 \mathrm{mmol})$ and $\mathrm{BP}(0.250 \mathrm{~g}, 1.37 \mathrm{mmol})$ in $\mathrm{CH}_{3} \mathrm{CN}(150$ $\mathrm{mL})$, placed in a pyrex flask was purged with $\mathrm{N}_{2}$ and irradiated in a photoreactor $\left(\lambda_{\max }=\right.$ $350 \mathrm{~nm}$ ) for six hours. Then, the solvent was concentrated under vacuum and the crude was purified by column chromatography $\left(\mathrm{SiO}_{2}, \mathrm{AcOEt}: \mathrm{Hex}, 70: 30\right)$ to yield $3[\mathrm{O}], 7[\mathrm{O}]-\mathrm{CAMe}(0.027 \mathrm{~g}, 4.8 \%), 3[\mathrm{O}]-\mathrm{CAMe}(0.041 \mathrm{~g}, 7.3 \%)$ and 7[O]-CAMe $(0.116$ $\mathrm{g}, 21 \%)$. After isolation each photoproduct was repurified by reverse phase column chromatography before characterization (Li Chroprep RP-18, $\mathrm{CH}_{3} \mathrm{CN}: \mathrm{H}_{2} \mathrm{O}, 60: 40$ ).

Characterization of 3[0],7[0]-CAMe. ${ }^{1} \mathrm{H}$ NMR (300 MHz, $\left.\mathrm{CDCl}_{3}\right): \delta(\mathrm{ppm}) 0.71$ (s, $\left.3 \mathrm{H}, 19-\mathrm{CH}_{3}\right) ; 0.97\left(\mathrm{~d}, J=6.0 \mathrm{~Hz}, 3 \mathrm{H}, 21-\mathrm{CH}_{3}\right) ; 1.28\left(\mathrm{~s}, 3 \mathrm{H}, 18-\mathrm{CH}_{3}\right) ; 2.86(\mathrm{dd}, J=13.2$ and $4.8 \mathrm{~Hz}, 1 \mathrm{H}) ; 3.66$ (s, 3H, $\left.\mathrm{CH}_{3} \mathrm{O}\right) ; 4.04$ (br s, $\left.1 \mathrm{H}, 12 \beta-\mathrm{H}\right) .{ }^{13} \mathrm{C} \mathrm{NMR}(75 \mathrm{MHz}$, $\left.\mathrm{CDCl}_{3}\right): \delta(\mathrm{ppm}) 210.8(\mathrm{C}), 210.4(\mathrm{C}), 174.7(\mathrm{C}), 72.1(\mathrm{CH}), 51.7\left(\mathrm{CH}_{3}\right), 49.7(\mathrm{CH})$, $47.8(\mathrm{CH}), 46.8(\mathrm{CH}), 46.7(\mathrm{C}), 45.1(\mathrm{CH} 2), 43.1\left(\mathrm{CH}_{2}\right), 40.8(\mathrm{CH}), 36.8\left(\mathrm{CH}_{2}\right), 36.2$ $(\mathrm{CH}), 35.5\left(\mathrm{CH}_{2}\right), 35.0(\mathrm{C}+\mathrm{CH}), 31.2\left(\mathrm{CH}_{2}\right), 31.0\left(\mathrm{CH}_{2}\right), 29.7\left(\mathrm{CH}_{2}\right), 27.7\left(\mathrm{CH}_{2}\right), 24.4$ $\left(\mathrm{CH}_{2}\right), 22.4\left(\mathrm{CH}_{3}\right), 17.7\left(\mathrm{CH}_{3}\right), 13.1\left(\mathrm{CH}_{3}\right) . \mathrm{m} / z$ found 419.2813 , calculated for $\mathrm{C}_{25} \mathrm{H}_{39} \mathrm{O}_{5}\left(\mathrm{MH}^{+}\right) 419.2797$.

Characterization of 3[O]-CAMe. ${ }^{1} \mathrm{H}$ NMR $\left(300 \mathrm{MHz}, \mathrm{CDCl}_{3}\right): \delta(\mathrm{ppm}) 0.72(\mathrm{~s}, 3 \mathrm{H}$, 19- $\mathrm{CH}_{3}$ ); 0.97 (m, 6H, 21- $\left.\mathrm{CH}_{3}+18-\mathrm{CH}_{3}\right) ; 3.39$ (dd, $J=15.0$ and $\left.13.5 \mathrm{~Hz}, 1 \mathrm{H}\right) ; 3.66$ (s, $\left.3 \mathrm{H}, \mathrm{CH}_{3} \mathrm{O}\right) ; 3.91$ (br s, $\left.1 \mathrm{H}, 7 \beta-\mathrm{H}\right) ; 4.02$ (br s, $\left.1 \mathrm{H}, 12 \beta-\mathrm{H}\right) .{ }^{13} \mathrm{C} \mathrm{NMR}(75 \mathrm{MHz}$, $\left.\mathrm{CDCl}_{3}\right): \delta(\mathrm{ppm}) 213.3(\mathrm{C}), 174.9(\mathrm{C}), 73.0(\mathrm{CH}), 68.4(\mathrm{CH}), 51.7\left(\mathrm{CH}_{3}\right), 47.4(\mathrm{CH})$, $46.8(\mathrm{C}), 45.7\left(\mathrm{CH}_{2}\right), 43.2(\mathrm{CH}), 42.0(\mathrm{CH}), 39.7(\mathrm{CH}), 37.0\left(\mathrm{CH}_{2}\right), 36.8\left(\mathrm{CH}_{2}\right), 35.3$ $(\mathrm{CH}), 35.0(\mathrm{C}), 34.0\left(\mathrm{CH}_{2}\right), 31.2\left(\mathrm{CH}_{2}\right), 31.0\left(\mathrm{CH}_{2}\right), 28.8\left(\mathrm{CH}_{2}\right), 27.6\left(\mathrm{CH}_{2}\right), 27.4(\mathrm{CH})$, $23.3\left(\mathrm{CH}_{2}\right), 21.8\left(\mathrm{CH}_{3}\right), 17.5\left(\mathrm{CH}_{3}\right), 12.7\left(\mathrm{CH}_{3}\right) . \mathrm{m} / \mathrm{z}$ found 443.2756 , calculated for $\mathrm{C}_{25} \mathrm{H}_{40} \mathrm{O}_{5} \mathrm{Na}\left(\mathrm{MNa}^{+}\right) 443.2773$.

Characterization of 7[O]-CAMe. ${ }^{1} \mathrm{H}$ NMR $\left(300 \mathrm{MHz}, \mathrm{CDCl}_{3}\right): \delta(\mathrm{ppm}) 0.68(\mathrm{~s}, 3 \mathrm{H}$, $\left.19-\mathrm{CH}_{3}\right) ; 0.97$ (d, $\left.J=6.0 \mathrm{~Hz}, 3 \mathrm{H}, 21-\mathrm{CH}_{3}\right) ; 1.18$ (s, 3H, 18- $\left.\mathrm{CH}_{3}\right) ; 2.83$ (dd, $J=12.4$ and $6.4 \mathrm{~Hz}, 1 \mathrm{H}) ; 3.58(\mathrm{~m}, 1 \mathrm{H}, 3 \beta-\mathrm{H}) ; 3.66$ (s, 3H, $\left.\mathrm{CH}_{3} \mathrm{O}\right) ; 4.01$ (br s, $\left.1 \mathrm{H}, 12 \beta-\mathrm{H}\right) .{ }^{13} \mathrm{C} \mathrm{NMR}$ (75 MHz, $\left.\mathrm{CDCl}_{3}\right): \delta(\mathrm{ppm}) 211.5(\mathrm{C}), 174.7(\mathrm{C}), 72.2(\mathrm{CH}), 71.1(\mathrm{CH}), 51.7\left(\mathrm{CH}_{3}\right), 49.7$ $(\mathrm{CH}), 46.7(\mathrm{CH}+\mathrm{C}), 46.2(\mathrm{CH}), 45.5\left(\mathrm{CH}_{2}\right), 40.9(\mathrm{CH}), 37.6(\mathrm{CH} 2), 36.1(\mathrm{CH}), 35.1$ $(\mathrm{CH}), 34.8(\mathrm{C}), 34.2\left(\mathrm{CH}_{2}\right), 31.2\left(\mathrm{CH}_{2}\right), 31.0\left(\mathrm{CH}_{2}\right), 30.0\left(\mathrm{CH}_{2}\right), 29.4\left(\mathrm{CH}_{2}\right), 27.7\left(\mathrm{CH}_{2}\right)$, 
$24.4\left(\mathrm{CH}_{2}\right), 23.0\left(\mathrm{CH}_{3}\right), 17.6\left(\mathrm{CH}_{3}\right), 13.0\left(\mathrm{CH}_{3}\right) . \mathrm{m} / \mathrm{z}$ found 421.2962 , calculated for $\mathrm{C}_{25} \mathrm{H}_{41} \mathrm{O}_{5}\left(\mathrm{MH}^{+}\right) 421.2954$.

\section{Irradiation of NaCA with KPMe}

A solution of $\mathrm{NaCA}(0.215 \mathrm{~g}, 0.5 \mathrm{mmol})$ and KPMe $(1.86 \mathrm{~g}, 0.5 \mathrm{mmol})$ in $100 \mathrm{~mL}$ of aqueous solution $\left([\mathrm{NaCl}]=0.2 \mathrm{M}\right.$ ), placed in a pyrex flask, was purged with $\mathrm{N}_{2}$ and irradiated in a photoreactor $\left(\lambda_{\max }=350 \mathrm{~nm}\right)$ for twelve hours. The kinetics of the photoreaction was analyzed at different times. The photoproducts in the crude were identified by comparison with isolated standards obtained upon saponification of $3[\mathrm{O}], 7[\mathrm{O}]-\mathrm{CAMe}, 3[\mathrm{O}]-\mathrm{CAMe}$ and $7[\mathrm{O}]-\mathrm{CAMe}$ in aqueous $\mathrm{NaOH}, 1 \mathrm{M}$. Quantification was based on area integration.

\section{Acknowledgements}

Financial support from the Spanish Government (Grants SEV-2012-0267 and CTQ2012-38754-C03-03), Generalitat Valenciana (Prometeo Program) and the Technical University of Valencia (Predoctoral FPI fellowship for P. Miró) is gratefully acknowledged.

\section{Notes and references}

1. A. F. Hofmann, Arch. Intern. Med., 1999, 159, 26472658 CrossRef CAS PubMed.

2. A. F. Hofmann and L. R. Hagey, Cell. Mol. Life Sci., 2008, 65, 24612483 CrossRef CAS PubMed.

3. A. F. Hofmann, L. R. Hagey and M. D. Krasowski, J. Lipid Res., 2010, 51, 226246 CrossRef CAS PubMed.

4. A. F. Hofmann and K. J. Mysels, Colloids Surf., 1988, 30, 145173 CrossRef CAS.

5. A. F. Hofmann, Am. J. Surg., 1989, 158, 198-204 CrossRef CAS PubMed.

6. M. J. Armstrong and M. C. Carey, J. Lipid Res., 1982, 23, 70-80 도.

7. D. M. Small, S. A. Penkett and D. Chapman, Biochim. Biophys. Acta, 1969, 176, 178-189 CrossRef CAS.

8. M. Gomez-Mendoza, M. L. Marin and M. A. Miranda, J. Phys. Chem. Lett., 2011, 2, 782-785 CrossRef CAS.

9. M. Gomez-Mendoza, M. L. Marin and M. A. Miranda, J. Phys. Chem. B, 2012, 116, 14776-14780 CrossRef CAS PubMed.

10. J. M. Ridlon, D.-J. Kang and P. B. Hylemon, J. Lipid Res., 2006, 47, 241-

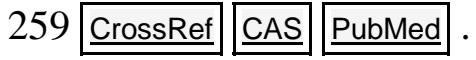


11. F. Secundo, G. Carrea, M. De Amici, S. Joppolo di Ventimiglia and J. S. Dordick, Biotechnol. Bioeng., 2003, 81, 391-396 CrossRef CAS PubMed.

12. V. Prabha and M. Ohri, World J. Microbiol. Biotechnol., 2006, 22, 191196 CrossRef CAS.

13. A. K. Agarwal and R. J. Auchus, Endocrinology, 2005, 146, 25312538 CrossRef CAS PubMed.

14. P. P. Giovannini, A. Grandini, D. Perrone, P. Pedrini, G. Fantin and M. Fogagnolo, Steroids, 2008, 73, 1385-1390 CrossRef CAS PubMed.

15. D. Monti, E. E. Ferrandi, I. Zanellato, L. Hua, F. Polentini, G. Carrea and S. Riva, Adv. Synth. Catal., 2009, 351, 1303-1311 CrossRef CAS.

16. G. Salen, A. Colalillo, D. Verga, E. Bagan, G. S. Tint and S. Shefer, Gastroenterology, 1980, 78, 1412-1418 CAS.

17. M. V. Encinas and J. C. Scaiano, J. Am. Chem. Soc., 1981, 103, 63936397 CrossRef CAS.

18. D. Z. Markovic, T. Durand and L. K. Patterson, Photochem. Photobiol., 1990, 51, 389-394 CrossRef CAS PubMed.

19. I. Andreu, I. M. Morera, F. Bosca, L. Sanchez, P. Camps and M. A. Miranda, Org. Biomol. Chem., 2008, 6, 860-867 도.

20. D. Neshchadin, F. Palumbo, M. S. Sinicropi, I. Andreu, G. Gescheidt and M. A. Miranda, Chem. Sci., 2013, 4, 1608-1614 조.

21. S. Kamijo, K. Tao, G. Takao, H. Tonoda and T. Murafuji, Org. Lett., 2015, 17, 3326-3329 CrossRef CAS PubMed. 